\section{Regards sur l'économie allemande}

Bulletin économique du CIRAC

$100 \mid 2011$

Varia

\title{
Réformes sociales
}

HASSEL A., SCHILLER C., Der Fall Hartz IV. Wie es zur Agenda 2010 kam und wie es weitergeht / PALIER B. (ed), A Long Goodbye to Bismarck? The Politics of Welfare Reform in Continental Europe

\section{(2) OpenEdition}

Édition électronique

URL : http://journals.openedition.org/rea/4240

DOI : $10.4000 /$ rea. 4240

ISBN : 978-2-8218-0894-2

ISSN : 1965-0787

\section{Éditeur}

CIRAC

Édition imprimée

Date de publication : 17 mars 2011

ISSN : 1156-8992

\section{Référence électronique}

«Réformes sociales », Regards sur l'économie allemande [En ligne], 100 | mars 2011, mis en ligne le 19 septembre 2011, consulté le 22 septembre 2020. URL : http://journals.openedition.org/rea/4240 ; DOl : https://doi.org/10.4000/rea.4240

Ce document a été généré automatiquement le 22 septembre 2020.

(c) CIRAC 


\section{Réformes sociales}

HASSEL A., SCHILLER C., Der Fall Hartz IV. Wie es zur Agenda 2010 kam und wie es weitergeht / PALIER B. (ed), A Long Goodbye to Bismarck? The Politics of Welfare Reform in Continental Europe

\section{RÉFÉRENCE}

HASSEL A., SCHILLER C., Der Fall Hartz IV. Wie es zur Agenda 2010 kam und wie es weitergeht, Campus Verlag, Francfort/New York, 2010, 348 p.

PALIER B. (ed), A Long Goodbye to Bismarck? The Politics of Welfare Reform in

Continental Europe, Amsterdam University Press, Amsterdam, 2010, 460 p.

1 Fondé sur une enquête très précise et des entretiens directs auprès des acteurs impliqués, le premier ouvrage retrace minutieusement la genèse des lois Hartz et de l' Agenda 2010 au sein de l'équipe des conseillers et des ministres du Chancelier Schröder. L'étude est également très instructive sur les forces et les positions en présence, notamment au sein du SPD et des syndicats, mais aussi des commissions d'experts qui ont pris part à l'élaboration de la stratégie de changement et de réforme du Chancelier, véritable réussite politique se soldant néanmoins par un échec électoral personnel. Le second ouvrage, qui compare et évalue les réformes de la protection sociale en Europe, comporte une analyse intéressante du cas allemand et de ses particularités, due au Prof. Karl Hinrichs, spécialiste réputé de la comparaison des politiques sociales à l'Université de Brême. (rl) 